David H. Gent

U.S. Department of Agriculture-Agricultural Research Service and Oregon State University, Corvallis

Lindsey J. du Toit

Washington State University, Northwestern Washington Research and Extension Center, Mount Vernon

Scott F. Fichtner

Western Farm Service, Clovis, CA
S. Krishna Mohan

University of Idaho, Parma Research and Extension

Center, Parma

Hanu R. Pappu

Washington State University, Pullman

Howard F. Schwartz

Colorado State University, Fort Collins, USA

\title{
Iris yellow spot virus: An Emerging Threat to Onion Bulb and Seed Production
}

\begin{abstract}
Onion (Allium cepa) is an economically important crop in the United States, generating over $\$ 900$ million annually in farm receipts from 2000 to 2004 (88). U.S. onion production area ranges from 65,000 to 70,000 hectares annually, with over $80 \%$ of the summer production $(54,000$ hectares) in the western states. On average, 53 million metric tons of onion bulbs are harvested annually from nearly 3 million hectares worldwide. A significant portion of the U.S. and world supply of onion seed is produced in the western United States, primarily in the Pacific Northwest (124).

The genus Allium includes various economically important cultivated species, including the bulb onion, chive (A. schoenoprasum), garlic (A. sativum), and leek (A. porrum) (10). At least 18 other Allium species are consumed as fresh vegetables, pickled, or used as flavoring. However, the bulb onion is the most economically valuable species. On average, worldwide production of garlic is valued at about $10 \%$ that of the bulb onion (10). Leek and bunching onion are the next most valuable
\end{abstract}

Corresponding author: H. F. Schwartz, Professor and Extension Plant Pathologist, Department of Bioagricultural Sciences and Pest Management, Colorado State University, Fort Collins 805231177; E-mail: howard.schwartz@colostate.edu

The use of trade, firm, or corporation names in this publication is for the information and convenience of the reader. Such use does not constitute an official endorsement or approval by the United States Department of Agriculture or the Agricultural Research Service of any product or service to the exclusion of others that may be suitable.

DOI: 10.1094/PD-90-1468

(C) 2006 The American Phytopathological Society species, with production concentrated in Europe and the Orient, respectively. Bunching onion (A. fistulosum) production also is important in some areas of the United States, such as California.

The distinctive flavor or odor of Allium spp. is produced when plant tissues are bruised or cut, and the enzyme alliinase hydrolyzes S-alk(en)yl cysteine sulfoxide precursors to form volatile sulfur compounds (10). Onion, garlic, and their relatives, although primarily grown for food, are also used in traditional medicine, including the treatment of chicken pox, the common cold, influenza, measles, and rheumatism. Antimicrobial characteristics of alliums are likely the result of sulfur compounds. Research has demonstrated that extracts of onion and garlic decrease sugars, lipids, and platelet aggregation, and enhance fibrinolysis in blood, indicating that alliums may help prevent arteriosclerosis and other cardiovascular diseases (111).

\section{History of Iris yellow spot virus in the United States and the World}

A pathogen, described as Tomato spotted wilt virus (TSWV), was reported affecting onion inflorescence stalks (scapes) in southern Brazil in 1981 (28). The disease was characterized by symptoms of chlorotic and necrotic eye-like or diamondshaped lesions on scapes (97), and later was referred to as "sapeca" (97). Similar symptoms were observed in the United States in summer of 1989 in onion seed crops in the Treasure Valley of southwestern Idaho and eastern Oregon (USA) (78). Symptoms appeared as chlorotic or necrotic, straw-colored to white, dry, elongate or spindle-shaped lesions along the scape, with lesions frequently more numerous at mid- to lower portions of the scape (Fig. 1A to E). In some lesions, an island of green tissue developed in the center of the necrotic area (Fig. 1C). When lesions became large and numerous, they coalesced, often completely girdling the scape. This weakened the scape, causing the seed head to collapse and topple over (Fig. 1G). Patterns of disease incidence in fields or locations were not apparent, nor was there any association with host genotype or cultural practices. Estimated yield losses in individual fields ranged from insignificant to nearly $60 \%$ (78).

Transmission electron microscopy of extracts and thin sections of symptomatic scape tissue revealed the presence of virus particles morphologically similar to TSWV (51). Inoculation of Gomphrena globosa with sap prepared from symptomatic tissues resulted in development of necrotic lesions; however, serological tests for TSWV and Impatiens necrotic spot virus (INSV) were negative. Together, these results indicated the possible involvement of a new tospovirus (77), although tospoviruses infecting onion had been reported previously $(60,120)$. Subsequently, Moyer and Mohan (83) and Hall et al. (51) reported the transmission of two tospovirus-like viruses from symptomatic scapes to Nicotiana benthamiana. One group of isolates reacted strongly with polyclonal and monoclonal antisera to INSV, whereas the second group of isolates did not react with INSV or TSWV antisera. In 1992-93, this new onioninfecting tospovirus was detected in vegetative tissues of onion seed crops from Idaho, Oregon, Arizona, and California (USA) by inoculation of $N$. benthamiana 
followed by Western blot analysis. The virus was also detected in leek and chive seed crops in Idaho (K. Mohan and J. was not reported from that country again until 1994, when it was detected in northeastern Brazil (97); the authors of the report described the causal agent of sapeca in onion as a tospovirus with a serologically distinct nucleocapsid protein.

In 1998, Cortes et al. (18) described Iris yellow spot virus (IYSV) in the Netherlands as a new tospovirus naturally infecting iris (Iris hollandica) in the field and leek in the greenhouse. Near the same time, Gera et al. (45) reported that IYSV caused a disease referred to as "straw bleaching" on onion in Israel, which was characterized by straw-colored ring spots on leaves (Fig. 2A and B) and flower stalks that sometimes coalesced and caused preMoyer, unpublished). The disease in Brazil mature plant death (Fig. 3A). The follow-

ing year, an isolate of the tospovirus causing sapeca was identified as IYSV based on biological, serological, and molecular data (96). Kritzman et al. (61) reported natural IYSV infection of lisianthus (Eustoma russellianum) grown in the field in Israel. The "onion isolate" of the tospovirus identified in the United States from 1989 also proved to be IYSV based on molecular and serological data (82).

Based on recent accounts, IYSV is now known to occur on onion in the following locations: 1999, India $(63,99)$; 2000, Slovenia (70); 2002, Colorado (USA) (108); 2003, Australia (21,55), Italy (19); 2004, Japan (86), Georgia (USA) (85), New Mexico (USA) (24), Washington (USA) (33); 2005, Chile (105), Peru (84,89), Spain (16), Tunisia (7), central Oregon (USA) (25); and 2006, Reunion Island (103), Guatemala (89), Texas (USA) (74), and New York (USA) (C. Hopeting, per-

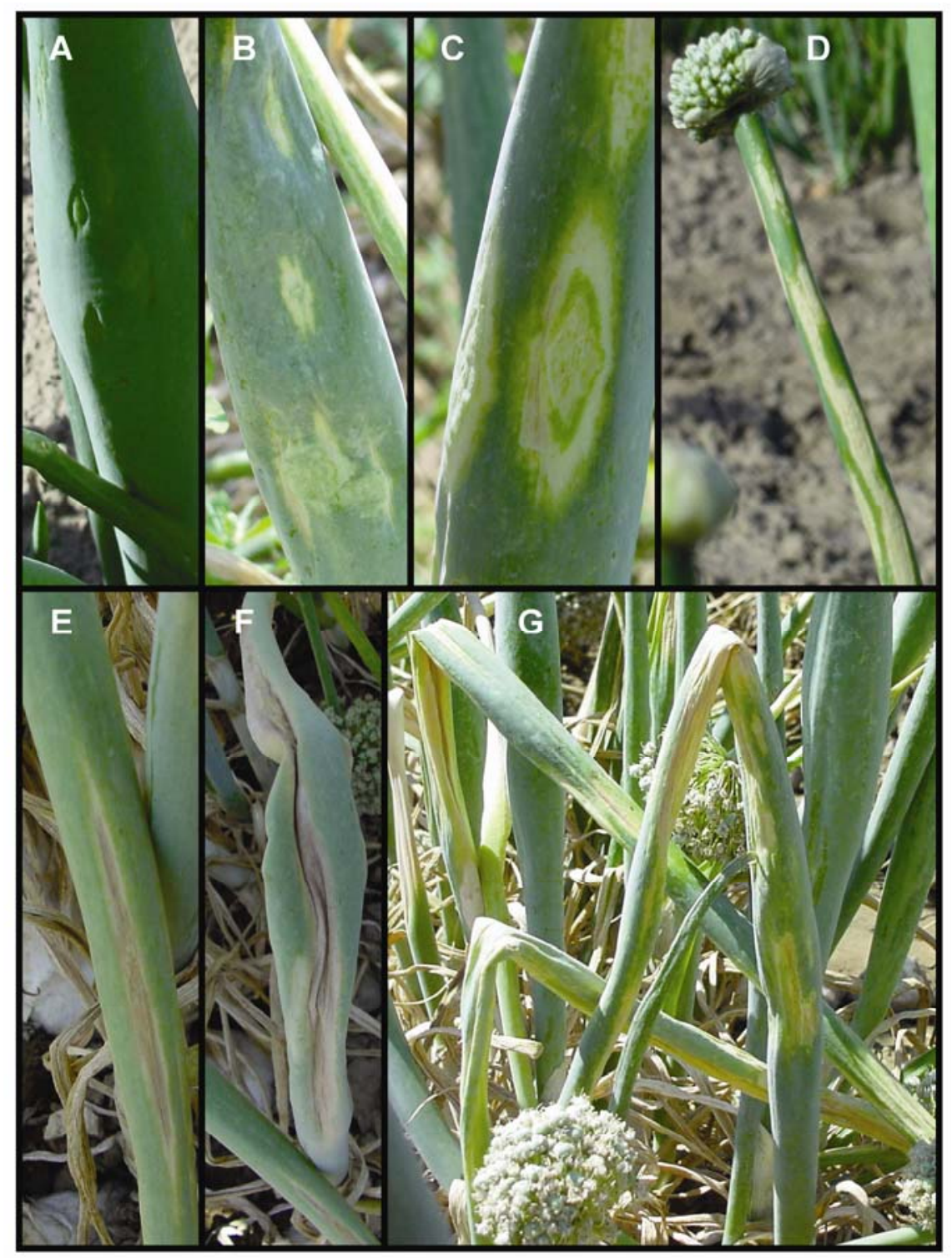

Fig. 1. Symptoms caused by Iris yellow spot virus in onion seed crops, including lenticular-shaped lesions with (B and $C$ ) or without (A and $D)$ green islands, and extensive necrotic lesions that cause lodging of the scapes ( $E$ to $G)$. sonal communication). To our knowledge, the pathogen has not yet been introduced into other onion-producing regions of the midwestern United States (i.e., Michigan, North Dakota) and Ontario, Canada.

With increased awareness of the characteristic symptoms of iris yellow spot, together with the availability of rapid diagnostic protocols, it is likely that IYSV will be found in onion crops in many other parts of the world. Some evidence suggests iris yellow spot, or a disease with similar symptoms, may also be caused by TSWV or co-infection of TSWV and IYSV. Mullis et al. (85) found that nearly $7 \%$ of the onion plants with iris yellow spot-like symptoms in Georgia (USA) were infected with TSWV and IYSV. TSWV has not been reported on onion outside of Georgia (USA), and the significance of TSWV infection or co-infection with IYSV on onion remains speculative.

To date, at least 47 plant species have been reported to be infected naturally by IYSV under field conditions $(7,18,31,43-$ $45,47,61,85,86,93,103)$. Reported natural hosts of IYSV or its variants include iris, onion, leek, chive, shallot (A. cepa var. ascalonicum), garlic, certain wild Allium species, prairie gentian/lisianthus (Eustoma russellianum, E. grandiflorum), Alstroemeria sp., amaryllis (Hippeastrum hybridum), Amaranthus retroflexus, and Portulaca oleracea. Ghotbi et al. (47) reported IYSV from Cycas sp., Pelargonium hortorum, Rosa sp., and Scindapsus sp. in Iran (Table 1). In Georgia (USA), S. W. Mullis, R. D. Gitaitis, D. B. Langston Jr., J. L. Sherwood, D. G. Riley, A. C. Csinos, A. N. Sparks, R. L. Torrance, and M. J. Cook IV (personal communication) found 20 weed species that tested positive serologically for IYSV; the most commonly infected weeds were Vicia sativa, Geranium carolinianum, and Linaria canadensis. Ben Moussa et al. (7) reported detecting IYSV in pepper (Capsicum annuum), potato (Solanum tuberosum), and tomato

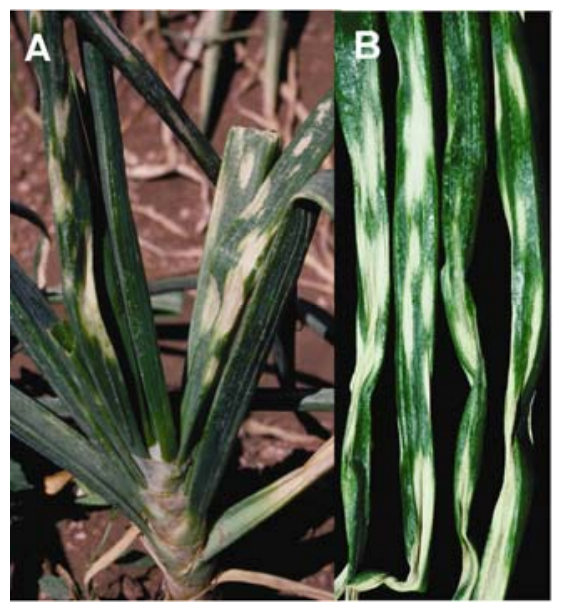

Fig. 2. Straw-colored lesions caused by Iris yellow spot virus on an onion plant (A) and on individual onion leaves (B). 
(Lycopersicon esculentum) in Tunisia. It is unclear if these hosts were infected naturally or by artificial inoculation, and what, if any, disease symptoms were produced on these hosts. To our knowledge, this is the only report of IYSV infection of solanaceous hosts, other than Nicotiana benthamiana and $N$. rustica indicator plants

Gent et al. (41) reported the rapid expansion of iris yellow spot in onion production regions of Colorado (USA). In two years, iris yellow spot went from being detected in 6 to $73 \%$ of the fields surveyed in the eastern and western production areas, but it was not detected in onion fields in northeastern and southern Colorado $(51,96)$

(USA) until 2004 and 2006, respectively. The epidemic of iris yellow spot in Colorado (USA) in 2003 was estimated to have cost growers $\$ 2.5$ to $\$ 5.0$ million in farm receipts alone, based on a conservative 5 to $10 \%$ loss of a $\$ 50$ million annual revenue (H. F. Schwartz and D. H. Gent, unpublished). If this rate of spread and damage were to continue, projected economic impact in the western United States could reach $\$ 60$ million (10\% loss) to $\$ 90$ million $(15 \%)$, in addition to environmental and economic costs due to additional pesticide sprays for thrips control $(\$ 7.5$ to $\$ 12.5$ million dollars for three to five additional sprays on 48,500 hectares per year). Iris yellow spot represents an immediate
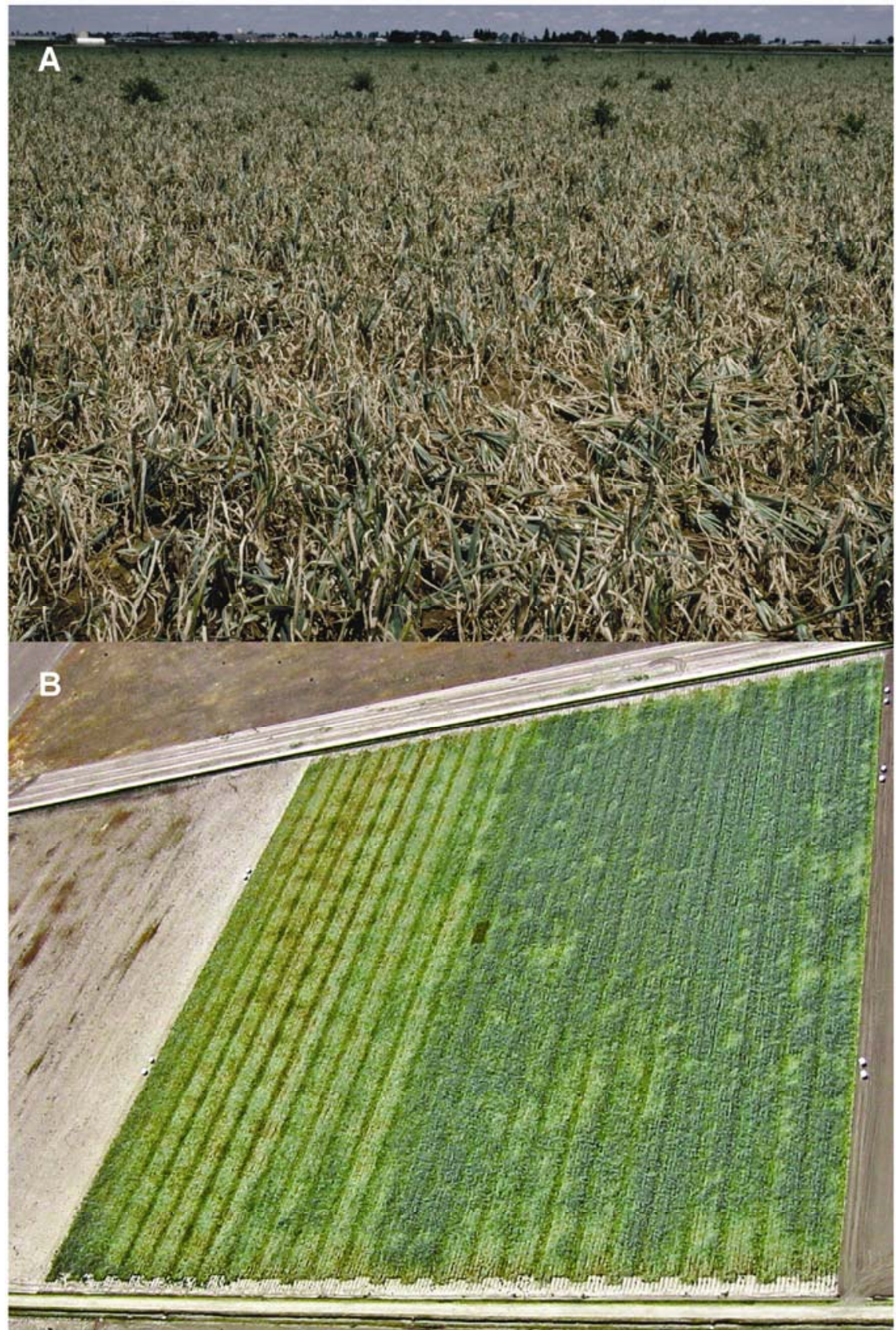

Fig. 3. Severe outbreak of iris yellow spot in an onion bulb crop in Colorado (USA) (A) and an onion seed crop in Oregon (USA) (B). Note the prevalence of disease along the margins of the seed crop, and the gradient of disease across the seed crop. and serious threat to sustainable and productive onion cropping systems in the United States, and the recent detection of this disease in numerous onion-producing countries underscores the need to develop economically sound and effective IPM strategies (8).

\section{Epidemiology of Iris Yellow Spot and the Onion Thrips Vector}

Onion thrips as a vector of IYSV. IYSV is transmitted by the onion thrips, Thrips tabaci $(18,62,87)$. Transmission of IYSV has not been reported with populations of Frankliniella occidentalis or $F$. schultzei $(62,87)$, although these thrips species have a broad host range and are efficient vectors of other tospoviruses on numerous plants $(55,66)$. Studies in Israel demonstrated a positive relationship between the incidence of $T$. tabaci in onion crops and the incidence of plants infected with IYSV (62). Similar to other tospoviruses $(126,128)$, IYSV is thought to be acquired by larvae of $T$. tabaci, with transmission occurring by second larval instars and adults only after circulation and replication in the vector.

Spatial and temporal patterns of iris yellow spot epidemics. The spatial and temporal patterns of spread of iris yellow spot in onion crops are largely unknown. Disease incidence varies within and among onion fields and depends on cultivar, plant population, and location in the field (41). Distinct directional disease gradients commonly are observed in fields during epidemics (Fig. 3B), but the significance and basis of these disease gradients remain unclear. In Colorado (USA), disease gradients were not consistently related to prevailing wind direction or the bordering crop (41), but more likely reflected a complex interaction of host susceptibility related to plant stress, proximity to an inoculum source, and vector dispersal and abundance over time. A low but significant degree of spatial autocorrelation in disease incidence has been documented in onion bulb crops (41), indicating aggregation of diseased plants and possibly secondary spread of the virus within fields.

The severity of epidemics of iris yellow spot varies from year to year, although the incidence of symptomatic plants generally increases markedly after bulb initiation. In preliminary studies, Fichtner et al. (38) and Hammon (52) found only trace levels ( $<3 \%$ incidence) of symptoms were apparent in onion fields before bulb initiation, with the incidence of disease increasing to $40 \%$ or greater as plants approached maturity. The timing of plant infection by IYSV remains uncertain. Surveys of summer bulb crops in eastern Colorado (USA) found a low incidence $(<2 \%)$ of infected plants soon after emergence (38). However, the timing of infections varies among onion bulb and seed crops. Although severe seedling infection was documented in one fall direct-seeded onion seed crop in 
Washington, symptoms typically develop most rapidly in onion seed crops after emergence of the scapes in late spring in this region (35). In Georgia (USA), infections appear to occur in the fall soon after planting, which can cause stand establishment problems; whereas severe epidemics of the disease have not been reported closer to harvest (85).

The association in space and time of populations of T. tabaci with outbreaks of iris yellow spot has been suggested in several studies $(38,62)$, although quantitative evaluations of the relationships of vector populations with iris yellow spot epidemics have not been reported. Kritzman et al. (62) suggested a relationship between populations of $T$. tabaci and the incidence of IYSV infection on onion crops in Israel, although the association of disease with population density of the vector was not quantified.

Detection of IYSV in onion plants. IYSV is distributed unevenly within onion plants. The highest titers of the virus are usually detected in the inner (younger) onion leaves at the center of the whorl or neck, the site where thrips preferentially reside and feed (62). Unlike TSWV, IYSV infections do not appear to become systemic in onion or other host species, and reliable detection of IYSV using enzymelinked immunosorbent assay (ELISA) can be problematic. The virus typically is not present in all leaves, and generally only is detected by ELISA in tissue sampled within 30 to $50 \mathrm{~mm}$ of visible lesions (S. F. Fichtner and H. F. Schwartz, unpublished). Although ELISA has been used extensively for detection of IYSV $(18,21,41$, $47,62,103,117)$, detection sensitivity is relatively low, and false negative results, even from symptomatic tissues, have been reported $(33,41)$. Problems with false negatives can be reduced by macerating tissues in liquid nitrogen prior to the addition of extraction buffer in ELISA (41), or by using reverse-transcription polymerase chain reaction (RT-PCR) assays to detect IYSV $(16,18,21,33,90,93)$. Smith et al. (117) reported false positive results with ELISA, and they developed a modified procedure and sampling protocol to minimize false positives and improve the reliability of IYSV detection from leek.

IYSV does not appear to be seedborne or seed-transmitted in onion (62). Kritzman et al. (62) did not detect IYSV in the bulbs or roots of infected onion or Hippeastrum plants in Israel. Roubene-Soustrade et al. (103) surveyed onion production fields in Reunion Island, France, and found that $75 \%$ of symptomatic leaves and $27 \%$ of bulbs tested positive for IYSV using ELISA. This is the only report of bulb infection by IYSV, but it suggests there is a potential for spread of IYSV by distribution of infected bulbs or culled bulbs, as documented for TSWV in the bulbs of Dahlia sp. (29).
Population structure and sequence characteristics of IYSV isolates. IYSV belongs to the genus Tospovirus and consists of a segmented genome with three genomic RNAs: large (L), medium (M), and small (S) (81). Considerable serological divergence exists among tospoviruses, as indicated by a lack of cross reaction among antisera to some of the distinct virus species within the genus $(18,96)$. The nucleotide sequences of the $\mathrm{M}$ and $\mathrm{S}$
RNAs of IYSV are available, making PCR-based detection of the virus now possible $(17,18,60,61,92,96)$. Molecular studies of IYSV and the sequence diversity among isolates collected from several countries and the western United States have been reported $(1,61,92)$. Kritzman et al. (61) demonstrated that isolates of IYSV obtained from onion and Hippeastrum were identical serologically, and that a $32.5 \mathrm{kDa} M_{\mathrm{r}}$ observed by polyacrylamide

Table 1. Plants reported to be naturally infected with Iris yellow spot virus (IYSV)a

\begin{tabular}{|c|c|c|}
\hline Host & Location $^{\text {b }}$ & Year of first report (reference) \\
\hline Allium altaicum & Washington & $2006(93)$ \\
\hline \multirow[t]{24}{*}{ A. сера } & Idaho & $1993(51)$ \\
\hline & Brazil & 1994 (97) \\
\hline & Israel & $1998(43)$ \\
\hline & Japan & $1999(63)$ \\
\hline & Slovenia & $2000(70)$ \\
\hline & Colorado & 2002 (108) \\
\hline & Arizona & $2003(82)$ \\
\hline & California & $2003(82)$ \\
\hline & Utah & $2003(1)$ \\
\hline & Italy & 2003 (19) \\
\hline & Australia & $2003(21)$ \\
\hline & New Mexico & $2004(24)$ \\
\hline & Washington & 2004 (33) \\
\hline & Georgia & $2004(85)$ \\
\hline & Tunisia & $2005(7)$ \\
\hline & Spain & 2005 (16) \\
\hline & Oregon & $2005(25)$ \\
\hline & Chile & 2005 (105) \\
\hline & India & 2006 (99) \\
\hline & Rèunion Island & 2006 (103) \\
\hline & Peru & $2006(84)$ \\
\hline & Texas & $2006(74)$ \\
\hline & Guatemala & $2006(89)$ \\
\hline & New York & 2006 (C. Hopeting, personal comm.) \\
\hline A. cepa var. ascalonicum & Rèunion Island & $2005(103)$ \\
\hline \multirow[t]{2}{*}{ A. porrum } & Australia & $2003(21)$ \\
\hline & Rèunion Island & $2005(103)$ \\
\hline A. sativum & Rèunion Island & $2005(103)$ \\
\hline A. pskemense & Washington & $2006(93)$ \\
\hline A. schoenoprasum & Idaho & $2003(89)$ \\
\hline A. vavilovii & Washington & $2006(93)$ \\
\hline Alstroemeria sp. & Japan & $2001(90)$ \\
\hline Amaranthus retroflexus & Colorado & 2004 (Schwartz et al., unpublished) \\
\hline Bessera elegans & Japan & $2005(55)$ \\
\hline Clivia minata & Japan & $2005(55)$ \\
\hline Cycas sp. & Iran & $2005(47)$ \\
\hline Eustoma grandiflorum & Japan & $2003(31)$ \\
\hline Eustoma russellianum & Israel & $2000(61)$ \\
\hline Geranium carolinianum & Georgia & 2004 (Mullis et al., personal comm. ${ }^{\mathrm{c}}$ ) \\
\hline Hippeastrum hybridum & Israel & $1998(45)$ \\
\hline Iris hollandica & The Netherlands & $1996(29)$ \\
\hline Linaria canadensis & Georgia & 2004 (Mullis et al., personal comm.) \\
\hline Pelargonium hortorum & Iran & $2005(47)$ \\
\hline Petunia hybrida & Iran & $2005(47)$ \\
\hline Portulaca oleracea & Colorado & 2004 (Schwartz et al., unpublished) \\
\hline Portulaca sp. & Italy & $2003(19)$ \\
\hline Rosa sp. & Iran & 2005 (47) \\
\hline Scindapsus sp. & Iran & $2005(47)$ \\
\hline Vicia sativa & Georgia & 2004 (Mullis et al., personal comm.) \\
\hline Vigna unguiculata & Iran & $2005(47)$ \\
\hline
\end{tabular}

a Chenopodium amaranticolor, C. quinoa, Datura stramonium, Gomphrena globosa, Nicotiana benthamiana, and $N$. rustica are reported as experimental hosts of IYSV.

b The following states are located in the United States: Arizona, California, Colorado, Georgia, Idaho, New Mexico, Oregon, Texas, Utah, and Washington.

c S. W. Mullis, R. D. Gitaitis, D. B. Langston Jr., J. L. Sherwood, D. G. Riley, A. C. Csinos, A. N. Sparks, R. L. Torrance, and M. J. Cook IV indicated IYSV was detected in 20 weed species in Georgia based on serological assays (double-antibody sandwich enzyme-linked immunosorbent assay). Only hosts reported in a poster presentation at the 2004 National Allium Research Conference in Grand Junction, CO, are listed in this table. 
gel electrophoresis for the nucleocapsid protein of these isolates was consistent with those published for a Dutch isolate of IYSV (18). The amino acid sequence of the nucleocapsid protein of an onion isolate of IYSV showed 99\% identity with a lisianthus isolate, and the two isolates showed 96 and $91 \%$ identity with a Dutch and a Brazilian isolate of IYSV, respectively (61).

Phylogenetic analysis of the nucleoprotein sequence of IYSV isolates from the western United States revealed three distinct populations (92) (Fig. 4). One clade (I) consisted largely of U.S. isolates (Cali- fornia, Colorado, Idaho, Oregon, Texas, Utah, and Washington). Within clade I, subclade Ia had two isolates from Japan, while subclade $\mathrm{Ib}$ consisted of isolates from the western United States. Clade II largely consisted of isolates from other countries with the exception of isolates from California and Oregon. The clustering of isolates from California in clades I and II was reported recently (92), and may suggest multiple introductions of IYSV at different times. IYSV isolates from Brazil and Slovenia showed significant divergence from those in clade II. Isolates from Chile formed a third clade which was re-

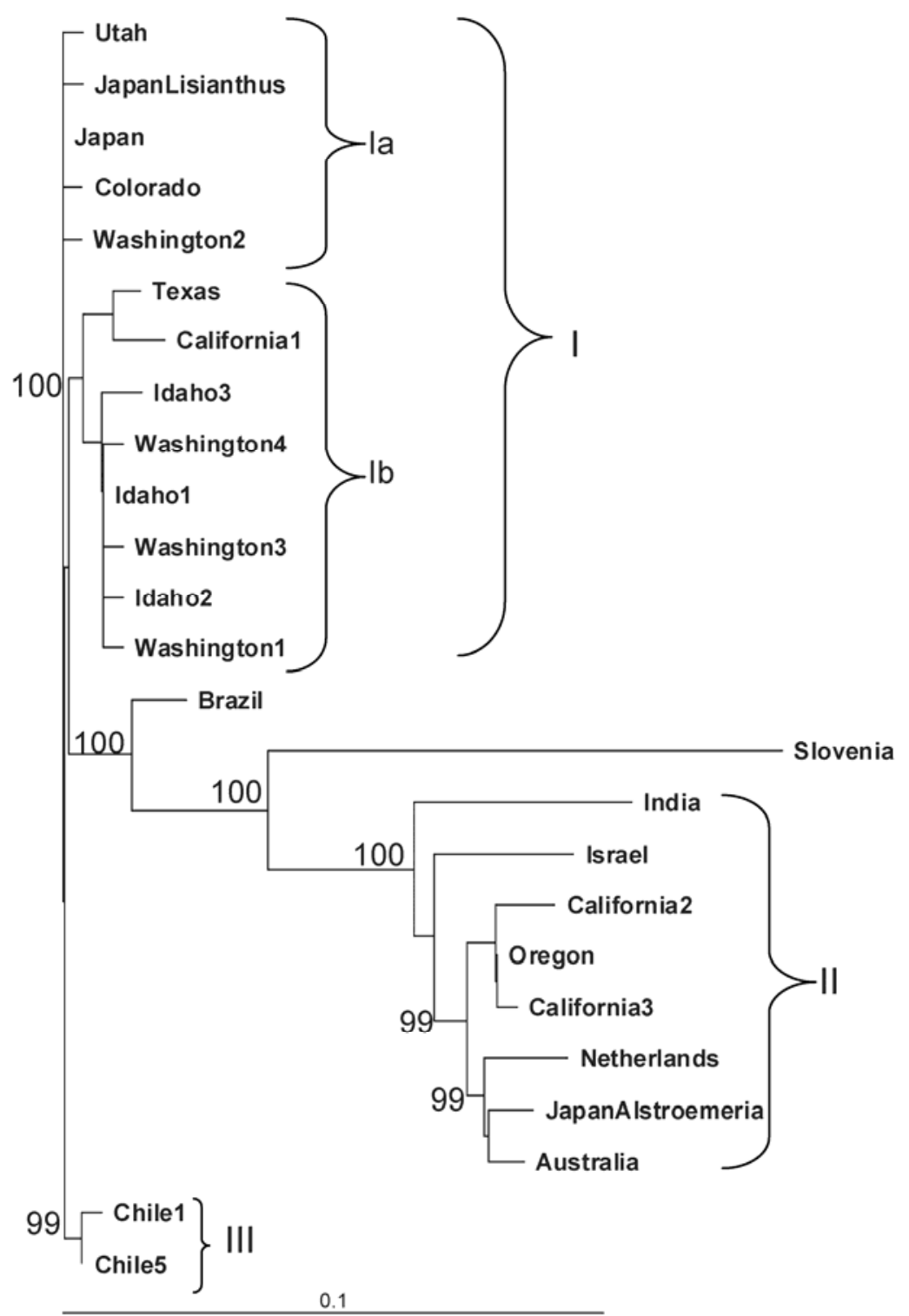

Fig. 4. Cluster dendrogram based on the amino acid sequences deduced from the nucleoprotein gene sequences of isolates of Iris yellow spot virus (IYSV) from the western United States and other countries. Representative sequences of the IYSV N gene obtained from GenBank were chosen for comparisons of hosts and region of origin. Isolate designation is the state or country of origin and host from which IYSV was recovered. Isolates were from onion unless indicated by the name of the host following the origin; all Washington isolates were from onion except Washington4, which was from shallot. The phylogenetic tree was made based on 1,000 puzzling steps and was generated as an unrooted tree. The percent reliability value given above each branch indicates how often the corresponding cluster was found among the 1,000 intermediate trees. Vertical length of the branches is arbitrary. ported to contain isolates from Georgia (USA), Peru, and Guatemala (89). The clustering of Georgia isolates with those from Peru suggests possible introduction of IYSV from Peru (89). Overall, phylogenetic analysis based on the $\mathrm{N}$ protein sequences indicates clustering of isolates based on geographic origin to some extent. Such divergence based on geographic origin was also noted for TSWV $(94,125)$, and is consistent with earlier reports for IYSV (1). Abad et al. (1) also detected a subgroup of isolates from infected chive, and suggested that this group may constitute a tospovirus that is distinct from IYSV.

The implications of the genetic diversity among isolates of IYSV remain speculative, although molecular studies point to multiple introductions of IYSV into the western United States. Genetic diversity among isolates of IYSV may indicate ecological or host specialization. Pozzer et al. (96) detected $9.5 \%$ divergence in the amino acid sequence of the nucleocapsid protein of an isolate of IYSV from onion in Brazil (designated IYSV $_{\mathrm{BR}}$ ) compared with an isolate from iris in the Netherlands. They suggested this divergence reflected an adaptation of the two isolates to different environmental conditions, as supported by differences in host range and host response. Unlike TSWV (128), genetic diversity among isolates of IYSV has not been associated with differences in vector specificity $(18,62,87)$.

Overwintering and alternate hosts. Numerous annual and perennial weeds serve as sources of TSWV and its thrips vectors, especially in the southeastern United States (50). Similarly, T. tabaci has an extremely broad host range, including weed hosts, especially common winter annuals such as mustard species. These weed hosts may serve as overwintering hosts for IYSV and the onion thrips vector in some onion-producing regions. Preliminary surveys of common weed species in and around onion fields with a history of iris yellow spot in Colorado (USA) in 2004 and 2005 revealed a low incidence of the virus in asymptomatic plants of redroot pigweed (Amaranthus retroflexus) and common purslane (Portulaca oleracea) as determined by ELISA (H. F. Schwartz, D. H. Gent, and S. F. Fichtner, unpublished). Similarly, S. W. Mullis, R. D. Gitaitis, D. B. Langston Jr., J. L. Sherwood, D. G. Riley, A. C. Csinos, A. N. Sparks, R. L. Torrance, and M. J. Cook IV (personal communication) reported detection of IYSV in 20 potential weed hosts in Georgia (USA) by ELISA. To our knowledge, however, no studies have documented thrips transmission of IYSV from a weed host to onion. In addition to weed hosts, IYSV also may survive on alternate crop hosts grown in the same region as onion. In the Bet-Shean Valley of Israel, the overlapping growing seasons of onion and 
Hippeastrum are thought to contribute inoculum for successive crops (62).

The association of IYSV with volunteer onion plants has been well established. In Colorado (USA), IYSV has been detected in volunteer onion plants, originating from bulbs left in the field at harvest, growing in ensuing crops of dry bean, alfalfa, field corn, and carrot (41). Symptomatic volunteer onion plants were detected as early as 1 March, nearly 4 weeks before the summer onion crop was planted, suggesting infected volunteers may provide a biological "bridge" between onion crops. IYSV typically is not present or detectable in onion bulbs or roots $(62,85)$, so the means by which volunteers become infected is uncertain. Volunteer onions may become infected soon after emergence early in the spring as a result of feeding by overwintering viruliferous thrips associated with the bulbs or with nearby plant debris. Alternatively, volunteers may initially be free of IYSV, and become infected by viruliferous thrips migrating from infected, and so far unidentified, overwintering weed host(s).

During 2004 and 2005, onion transplant seedlings removed directly from crates after transport from southwestern states where they were grown (i.e., Arizona and California, USA) were assayed for IYSV by ELISA. More than $50 \%$ of lots of onion transplants sampled from commercial shipments into Colorado (USA) during 2004 and 2005 exhibited symptoms of iris yellow spot, and the presence of the virus was confirmed by ELISA (110). The incidence of iris yellow spot symptoms among transplant seedlings within a lot ranged from 0.4 to $5.0 \%$. Additionally, T. tabaci and Frankliniella spp. were recovered from 18 and $91 \%$ of the lots sampled in 2004 and 2005, respectively (3 to 275 larvae and/or adults per 200 plants) (H. F. Schwartz, W. S. Cranshaw, and L. Mahaffee, unpublished). These and other surveys (109) strongly suggest transplants are a potential source of the virus and vector that may need to be addressed in the production of onion bulb and seed crops.

The importance of overwintering of IYSV in diapausing or quiescent thrips in the soil, or associated with plant debris, has not been investigated, but overwintering of viruliferous thrips in soil potentially could be a source of inoculum. However, overwintering of TSWV in $F$. fusca and other thrips vectors in the soil generally is minimal, and largely has been discounted as a primary means of survival of this virus $(6,14,50)$.

Epidemiological aspects of IYSV that differ from other tospoviruses. Although many epidemiological characteristics of iris yellow spot are similar to diseases caused by other tospoviruses, certain epidemiological and biological characteristics of IYSV appear distinct. Vector and host specificity appear to be narrower for isolates of IYSV compared with other to- spoviruses. At least nine species of thrips are known to vector strains of TSWV, but T. tabaci is the only known vector of IYSV $(46,62,87,126)$. More than 650 species of plants from over 50 families have been reported as hosts of TSWV $(46,126)$, but the host range of IYSV appears more limited, with most natural hosts in the Liliaceae (82). As stated above, at least 47 plant species have been demonstrated to be infected naturally by IYSV in the field. Although the host range of $T$. tabaci is very broad (66), the host range of IYSV is relatively limited and few of the known hosts are present at a time that would enable overwintering of the pathogen.

The propensity of thrips to develop very large populations on onion in short periods of time may strongly influence epidemics of iris yellow spot. Onion is a preferred host for T. tabaci, and this vector is a major pest of onion wherever it is grown (66). In contrast, tomato is a poor reproductive host of $F$. occidentalis, which is one of the primary vectors of TSWV on this crop (100). Lewis (65) estimated that 1 hectare of onion may contain 1.6 billion thrips larvae, a tremendous population size given the small stature of onion plants. If left untreated, thrips populations commonly approach 13 to 25 per leaf, although populations as low as 1 to 3 thrips per leaf are capable of causing economic injury in the absence of iris yellow spot $(37,39,114)$. The potential for large outbreaks of thrips, particularly in the warm and dry growing conditions found in much of the western United States, and the potential for thrips to predispose plants to disease may be central to the epidemiology of iris yellow spot.

Secondary spread of IYSV may be significant in disease epidemiology, although secondary spread of other tospoviruses generally has been regarded as of little consequence to epidemic development $(13,22,26,48,72,73,98)$. Several studies have suggested that secondary spread of tomato spotted wilt within fields is limited, and the general failure of insecticides to provide disease suppression is often ascribed to the lack of secondary spread of thrips within fields and the nearcontinuous immigration of viruliferous thrips into fields from weeds and/or other crops $(13,22,26,48,72,73,98)$. This is reasonable given that TSWV has a broad host range and commonly is found in weed populations $(26,47)$. Most studies of the spatio-temporal aspects of diseases caused by tospoviruses have been conducted with TSWV and crops of relatively large stature, such as tobacco and tomato. In contrast, the small stature of onion plants allows for dense plantings, compared with tobacco or tomato, and thrips may readily move between adjacent onion plants. Fichtner et al. (38) and Gent et al. (41) reported a small but significant degree of spatial autocorrelation in the incidence of iris yellow spot within onion fields in Colorado (USA). Here, iris yellow spot was first observed on the borders of the fields, but disease gradients later developed and extended into the fields. Disease gradients extended farther into the field and flattened with time, consistent with secondary spread of the disease from initial infection sites. Correspondingly, Hammon (52) observed a negative correlation between thrips control with insecticides and subsequent development of iris yellow spot. This suggests that secondary spread of viruliferous thrips may play a role in disease development.

Adopting management practices for iris yellow spot based primarily on research conducted on tospoviruses in other crops is further complicated by the limited ability of onion growers to modify cultural practices. For instance, altering planting dates and/or tillage systems and the use of UVreflective mulches have reduced tomato spotted wilt incidence in several crops $(26,69,80,101,102,112,118)$. Onion bulb and seed growers in the United States have had limited capacity to adopt these strategies because of the relatively short growing season of the more northern regions of onion production in the United States (necessitating uniform and early planting dates), the small size of onion seed (making limited or no-tillage practices impractical), and dense planting patterns (limiting the usefulness of UV-reflective mulches).

\section{Management of Iris Yellow Spot and Thrips}

Host resistance to thrips and iris yellow spot. Yield losses in onion crops caused by T. tabaci have been documented for decades, and still occur in most areas of onion production (66). Similarly, a wide range of yield losses associated with iris yellow spot has been documented in onion bulb and seed crops $(34,35,42,43,70,76,96,110)$. Losses resulting from thrips infestations depend on multiple factors, including size of thrips populations, conduciveness of weather conditions for growth of thrips populations, plant growth stage at the time of infestation, and susceptibility of cultivars to thrips feeding and oviposition damage and/or infection by viruses vectored by thrips (66). Although this complicates efforts to select for resistance to thrips and/or iris yellow spot in breeding programs, variation in susceptibility or tolerance to thrips among onion cultivars has been documented $(9,20,39,56,64,79,107$, 116,127). Likewise, differences in susceptibility of onion cultivars to iris yellow spot have been reported $(34,42)$. These findings highlight the potential role of breeding for resistance/tolerance to thrips damage and IYSV for more effective disease management.

Various mechanisms of antixenosis (morphological, physical, or structural plant traits that prevent or inhibit herbivores 
from finding, colonizing, and accepting the plant) and antibiosis (plant characteristics that prevent or inhibit development or reproduction of herbivores) have been associated with resistance to thrips in onion (66). Jones et al. (56) reported that a greater angle of divergence of the two innermost leaves and the vertical distance between leaf blades in the sheath column are associated with greater resistance of onion cultivars to thrips. Similar observations were made by Coudriet et al. (20) and Fournier et al. (39). Presumably, greater openness between the leaves increases thrips exposure to adverse environmental conditions and natural enemies, because thrips seek out narrow spaces on plants, such as leaf sheaths and inflorescences, to live and reproduce (66).

Although some research has indicated that white onion cultivars appear less susceptible to thrips damage than red cultivars $(2,64,107,127)$, this generalization does not always hold true. Brar et al. (9) screened 61 onion cultivars or breeding lines for resistance to T. tabaci and concluded that susceptibility of onion cultivars was not necessarily correlated with bulb color. In contrast, a strong correlation was demonstrated between thrips resistance and onion leaf color. The greater attraction of $T$. tabaci to blue hues versus green hues $(27,58,68)$ suggests that onion cultivars with blue-green foliage may suffer more damage from thrips feeding than cultivars with green foliage. Cultivars with glossy foliage tend to have a greater degree of resistance to thrips than cultivars with nonglossy foliage, probably because of differences in chemistry of the leaf waxes $(71,79)$ or decreased egg-hatching or larval feeding (106).

Al-dosari (2) quantified the tolerance of onion cultivars to onion thrips and found little evidence of differences in T. tabaci host suitability among cultivars (antixenosis and antibiosis resistance mechanisms). However, the cultivars varied widely in their response to onion thrips injury (tolerance resistance mechanism). Some cultivars suffered high losses from thrips, whereas others with similar levels of thrips infestation consistently had little or no yield response from thrips control. It is unclear if increased tolerance to thrips feeding injury will reduce iris yellow spot since tolerant cultivars may have higher economic-action thresholds for insecticide treatments.

Another potential method of minimizing losses to thrips and/or iris yellow spot is to take advantage of klendusity, i.e., the ability of an otherwise susceptible plant or cultivar to escape disease as a result of the pattern of growth or any mechanical hindrance to infection. For example, early maturing cultivars of onion may escape thrips infestations later in the season (127). More severe losses to iris yellow spot have been observed in hybrid and open pollinated seed crops in which the parental lines produce tall scapes that lodge more readily during windy conditions than scapes of shorter stature, if large or coalescing iris yellow spot lesions develop on the scapes of both plant types (35; L. J. du Toit, unpublished) (Fig. 1G). A negative correlation was demonstrated between seed yield and the incidence of scapes that lodged as a result of iris yellow spot lesions $(r=-0.84, P=0.0093)$ in an openpollinated seed crop with tall scapes (32). In contrast, very little lodging $(<1 \%)$ was observed in a hybrid seed crop with short scapes that displayed a similar incidence of infection ( $>80 \%$ of the scapes infected) to the open-pollinated seed crop (L. J. du Toit, unpublished). Seed growers located in regions with high risk of iris yellow spot could perhaps plant seed crops of cultivars that produce shorter scapes to reduce the risk of lodging and subsequent seed losses as a result of IYSV infection.

Efforts to screen onion cultivars for resistance to iris yellow spot revealed no cultivar or advanced breeding line that appeared to be immune to IYSV $(34,42)$. Complicating efforts to screen for resistance is the difficulty of differentiating resistance to thrips damage from resistance to iris yellow spot, along with inherent differences in yield potential among cultivars. In a 2004 field trial in Washington (USA) in which 46 onion cultivars were evaluated in replicated plots, the incidence of plants with symptoms of iris yellow spot ranged from 58 to $97 \%$ for individual cultivars (34). Similarly, field trials in Colorado (USA) showed a range in incidence of infected plants from 17 to $100 \%$ for 43 cultivars evaluated in 2003, and 14 to $62 \%$ for 46 cultivars evaluated in 2004 (42,110). Significant differences in marketable yield were detected among cultivars in all three trials. In the 2004 trial in Washington (USA), significant negative correlations were detected between incidence of plants with symptoms of iris yellow spot and total marketable yield $(r=$ -0.43 at $P=0.0029$ ) or percentage of jumbo bulbs ( $r=-0.41$ at $P=0.0046)$ (34).

Sanitation. Elimination of volunteer onion and planting of transplants free of IYSV and thrips are central to successful management of iris yellow spot in allium production. In Colorado (USA), severe epidemics of iris yellow spot in summer onion crops sometimes can be traced to infested volunteer onions or contaminated onion transplants $(42,110)$. Volunteer onion plants and contaminated transplants are the only sources of primary inoculum identified to date in the High Plains region of the United States, and may provide an important early-season source of inoculum to initiate outbreaks in neighboring onion crops. Interstate movement of infected onion transplants also could facilitate the spread of new strains of IYSV and biotypes of $T$. tabaci within and among regions of onion production.
The importance of weed control in management of iris yellow spot is unknown. Culbreath et al. (26) asserted that for a plant to be an important source of inoculum of TSWV it must: (i) be a host for the virus; (ii) support reproduction of the vector for at least one generation; (iii) allow for thrips larvae to acquire the virus; and (iv) be present at a time that complements the disease cycle. Based on these conditions, no weeds have been confirmed as important sources of IYSV. However, the known host range of IYSV is increasing steadily, and important reservoirs of the virus in weeds, other crops, and wild $\mathrm{Al}$ lium species may yet be identified. Therefore, it may be prudent to eliminate from areas of onion cultivation any wild, ornamental, or volunteer plants closely related to Allium species, as well as other known hosts of IYSV. Several summer annual weed species have been identified as hosts of IYSV, and these weeds may be important for within-season spread of the virus, or may provide a biological bridge between summer bulb crops and seed or bulb crops planted later in the season and lateseason winter annual weeds.

Crop rotation and isolation. Current understanding of the biology and epidemiology of IYSV and its vector is somewhat limited for development of effective crop rotation and crop isolation strategies. However, some general observations can be considered. The relatively limited host range of IYSV suggests that rotations of host with nonhost crops and spatial isolation of host crops may help limit spread of the virus within a region. Because the biennial season of onion seed crops provides a continuous "green bridge" for survival of IYSV and its vector through the winter, onion bulb and seed crops should be isolated geographically. Sufficient crop isolation may be critical in regions such as the Pacific Northwest (USA), where biennial seed crops, overwintering bulb crops, and summer bulb crops may be located in the same areas and have growing seasons that overlap by several months (35). Unfortunately, research on the isolation distances needed to prevent spread of IYSV among host crops is lacking, so current recommendations emphasize maximum separation among fields. Similarly, other hosts (i.e., chive, garlic, leek, and shallot) of IYSV should not be grown in the vicinity of onion crops.

Modified cultural practices. Modification of cultural practices may reduce the risk of severe epidemics of iris yellow spot. Consistent with reports of tomato spotted wilt in other cropping systems (11), increased and more uniform plant density appears to provide some control of iris yellow spot in onion crops. Gent et al. (41) and Fichtner et al. (38) demonstrated a negative relationship of plant population with incidence of plants showing symptoms of iris yellow spot in fields planted to 
moderately resistant onion cultivars. Plant population sometimes explained greater than $56 \%$ of the observed variability in disease incidence. This effect of plant population was not as apparent with more susceptible cultivars, and the significance of planting pattern on development of iris yellow spot remains unclear.

In general, there appears to be a relationship between plant stress, predisposition to damage by thrips, and severity of iris yellow spot $(75,110)$, although no studies have quantified the contribution of abiotic and biotic stresses to development of iris yellow spot. A sensible recommendation for pest management and production strategies, where possible, is to reduce stress to the onion crop from moisture extremes, compaction, and soilborne diseases such as pink root (caused by Phoma terrestris) and Fusarium basal rot (caused by Fusarium oxysporum f. sp. cepae). More research is needed on the role of plant stress and predisposition of onion to iris yellow spot.

In preliminary surveys conducted in Colorado and Washington (USA), overhead irrigation has consistently been associated with a reduced incidence and severity of iris yellow spot $(35,110)$. However, quantitative estimates of disease suppression provided by overhead irrigation are lacking. Thrips populations often decline in response to heavy rain (59), and overhead irrigation has been suggested as a means of suppressing thrips pests in various crops, including onion $(12,95)$. The interactions of irrigation, thrips populations, and iris yellow spot may be more complex than simply associated with mortality of thrips caused by overhead irrigation. Yield losses in onion resulting from thrips feeding injury are increased by stress from inadequate water supply $(39,95)$, and separating the effects of irrigation on thrips mortality from alleviation of moisture stress may be difficult. Further studies are warranted to determine the importance of irrigation method and management on suppression of iris yellow spot and onion thrips.

Thrips management. Onion growers in the western United States rely heavily on insecticides for management of thrips, and insecticidal management of T. tabaci as an indirect means of controlling iris yellow spot has been an area of study in recent years $(23,52)$. However, conventional insecticides such as the pyrethroids, organophosphates, and carbamates have become ineffective in some regions of onion production because of development of insensitivity to these insecticides in thrips populations $(3,113)$. Research is underway to identify reduced-risk and new insecticides for managing thrips $(53,54)$. For example, the insecticides spinosad and neem extract have shown promise for managing thrips in onion crops, based on studies conducted in Colorado and Oregon (USA) $(53,54 ;$ S. F.
Fichtner, D. H. Gent, H. F. Schwartz, R. Hammon, and W. S. Cranshaw, unpublished). In Colorado in 2004 and 2005, rotating applications of neem extract and spinosad, in combination with straw mulching, reduced thrips numbers compared with a conventional rotation of lamba-cyhalothrin and methomyl, and resulted in an increase in yield of jumbo grade bulbs (S. F. Fichtner, H. F. Schwartz, and W. S. Cranshaw, unpublished).

Mulches have been used to manage insect pests in many cropping systems $(30,80)$. Reflective mulches can reduce thrips populations by disrupting the ability of the thrips to recognize and alight on host plants, and UV-reflective mulches have proven useful in crops such as tomato for reducing thrips populations and development of tomato spotted wilt $(30,80,121)$. Unlike tomato crops, in which entire planting beds can be mulched, applying a UVreflective mulch to onion beds with multiple rows of plants is not practical, and studies in Colorado (USA) revealed only marginal reductions in thrips populations as a result of reflective mulches applied to the center of beds planted with two rows of onions. However, straw mulching appears promising for thrips management in onion crops $(53,54)$. In studies conducted in Colorado in 2005, straw mulch applied to the center of onion beds reduced thrips populations by as much as $48 \%$ (S. F. Fichtner, H. F. Schwartz, and W. S. Cranshaw, unpublished), with a corresponding increase in yield of $14 \%$ or greater. Although there was no apparent effect of the straw mulch treatment on iris yellow spot in these trials, additional studies are in progress to determine if straw mulching may suppress this disease. The mechanism(s) by which straw mulch suppresses thrips populations is not known, but conservation of natural predators of thrips has been suggested $(53,54)$. In field trials in Colorado (USA) in 2004 and 2005, differences in populations of minute pirate bugs (Orius tristicolor) and predatory thrips were not observed between different mulch types, although differences in light reflectance were detected between nontreated and straw-mulched plots. The mechanism of thrips suppression may also be indirect. Shock et al. (115) reported that, in the absence of thrips pressure, straw mulches applied to irrigation furrows increased onion yields by 64 to $74 \%$ due to decreased water runoff and increased lateral movement of soil moisture in mulched plots. Straw mulching may alleviate water stress in hot and dry growing conditions, potentially increasing onion tolerance to thrips feeding and indirectly increasing plant tolerance to iris yellow spot $(39,95)$.

Systemic acquired resistance. Improved management of plant diseases caused by tospoviruses in other cropping systems has been achieved through induction of systemic acquired resistance (SAR), most often through the application of exogenous chemicals such as salicylic acid or its structural analogs $(15,49,57,119)$. SAR is an induced plant resistance that is first localized to the site of infection, and then spreads systemically to distal noninfected tissues remote from the initial site of infection (119), triggering a range of defense mechanisms that include formation of phenolics, phytoalexins, callose, pathogenesis-related proteins, and hydroxyproline-rich glycoproteins.

Acibenzolar-S-methyl (Actigard, Syngenta Crop Protection, Greensboro, NC, USA) is a structural analog of salicylic acid in the benzothiadiazole class of SAR inducers (49). This SAR product has been demonstrated to minimize damage caused by a range of fungal, bacterial, and viral plant pathogens $(4,5,15,40,49,67,91,104)$. The potential value of SAR compounds for control of iris yellow spot was demonstrated by Gent et al. (42) in a field trial in Colorado (USA), in which a $34 \%$ reduction in incidence of plants with symptoms of iris yellow spot was observed, compared with nontreated controls, following four foliar applications of acibenzolar- $S$ methyl, with a corresponding increase in jumbo grade bulbs. In Florida, applications of acibenzolar- $S$-methyl reduced the incidence of tomato plants infected with TSWV by $28 \%$ in each of two seasons with high disease pressure, but had no significant effect on TSWV in a season with mild disease pressure (80). Applications of acibenzolar-S-methyl also reduced numbers of thrips (Frankliniella spp.) in tomato flowers on some dates, corroborating the work of Thaler et al. $(122,123)$ who established that applications of salicylic acid induce defensive proteins in plants that provide resistance to certain insects, including thrips. Data from field trials suggest acibenzolar- $S$-methyl may have little effect on thrips populations in onion crops (23), indicating that the effects of the product on iris yellow spot are a result of suppression of the virus rather than the vector and/or enhancement of host tolerance to thrips damage or IYSV.

Induced resistance involves complex physiological processes that may incur costs to the induced plants expressed as phytotoxicity or reduced yields. Gent and Schwartz (40) documented a 22 to $27 \%$ reduction in onion bulb yield when 10 weekly applications of acibenzolar- $S$ methyl were made in the absence of disease, although this was 2.5 times the maximum number of applications indicated on the Actigard 50WG label for registered crops. Cole (15) observed mild symptoms of phytotoxicity in tobacco seedlings caused by applications of acibenzolar- $S$-methyl, but not when the product was applied in the field after transplanting. The phytotoxic effects were overcome by applying a top dressing of calcium nitrate to the seedlings, and Cole 
suggested diversion of nitrogen or calcium into the SAR initiated metabolism (15). Further research is needed to determine optimum use of SAR products in onion crops (number, rate, and timing of applications) to maximize control of IYSV and thrips, while minimizing phytotoxic effects. Determining the optimum rate and timing of SAR products is critical for biennial seed crops because of the extended opportunity for IYSV infection during the 14- to 15-month growing season.

Integrated management of IYSV. Effective long-term management of IYSV in onion crops will depend on a multifaceted approach that integrates host resistance, modified cultural practices, and judicious use of chemical tools. An effective integrated management program was developed for tomato spotted wilt of tomato by Momol et al. (80), in which a combination of UV-reflective mulch, applications of acibenzolar-S-methyl, and applications of reduced-risk insecticides that conserve thrips predators was very effective at managing the disease. Momol et al. (80) stated that tomato growers in northern Florida and southern Georgia (USA) rapidly are adopting these management tools for control of TSWV. Similar efforts are needed to develop economically feasible and practical management options for iris yellow spot and onion thrips in onion crops.

\section{Outlook and Future Directions}

Since the original description of IYSV in 1998 (18), iris yellow spot has become pandemic in regions of onion bulb and seed production. The prolific nature of onion thrips in onion crops, the propensity for thrips to develop insecticide resistance, and the ability of onion thrips to vector IYSV present a serious threat to profitable and sustainable production of onion bulbs and onion seed. However, new knowledge about the biology, epidemiology, and management of iris yellow spot has emerged in a relatively short time, with a significant inventory of research accomplishments. The main vector of IYSV has been identified, insights into the diversity of the pathogen and its relation to other tospoviruses have been determined, alternate weed and crop hosts continue to be reported, and inoculum sources of the pathogen and vector have been identified. Moderate levels of disease resistance have been identified in some onion cultivars, and these may be suitable for commercial production and in breeding programs. Biologically based approaches for onion thrips management also have emerged. Additional research should lead to development of new management strategies so that iris yellow spot can be managed economically in both onion bulb and seed crops.

Short-term research directions. Many basic epidemiological questions on iris yellow spot remain to be addressed. Despite intensive use of insecticides for con- trol of iris yellow spot, the direct relationship between thrips control and reductions in disease incidence and/or severity have not been reported. A critical evaluation of the relationship of thrips control to disease development is needed to provide growers with sound IPM approaches for iris yellow spot. Although inoculum sources of IYSV have been identified, the relative contributions of these sources of inoculum are unclear. Additional overwintering sources and hosts of IYSV likely will be identified, and other vectors may yet be discovered. How long do thrips need to feed on infected plants to become viruliferous or to transmit IYSV? What is the transmission efficiency of different populations of $T$. tabaci, and what does this indicate about key reservoirs of the pathogen? Asymptomatic infections appear to be common in onion bulb and seed crops, but what is the role of such latent infections in development of iris yellow spot epidemics? What is the minimum isolation distance needed between bulb and biennial seed crops, or between onion and other host crops, to prevent dissemination of the virus, and what insights could this provide on inoculum sources and/or vector dispersal? What relationships exist among abiotic and biotic plant stresses, vector reproduction, and disease severity, and can these relationships be quantified? How do host nonpreference, plant architecture, and other thrips tolerance mechanisms impact primary and secondary spread of IYSV? Perhaps most importantly, how successfully can the disease be managed by integration of biological, chemical, and cultural control tactics?

A pressing research need is to develop management strategies for the disease in onion seed crops. The emerging body of knowledge on iris yellow spot has focused largely on onion bulb crops, and our knowledge of the epidemiology and management of the disease in onion seed crops is minimal. Onion seed crops are biennial with approximately a 14-month season from planting in July to harvest the following year. As a result, one seed crop season can overlap with two 5- to 6-month-long seasons of spring-planted bulb crops. Managing thrips and iris yellow spot over such a long period presents a serious challenge. Additionally, seed growers produce seed crops on a contract basis with seed companies, and generally do not have the choice to select less susceptible parental lines or cultivars. Management tactics developed for bulb crops need to be validated in seed crops, and may require additional measures to provide adequate control of the disease.

Long-term research directions. Longterm management of iris yellow spot likely will depend on development of onion cultivars with high levels of disease resistance. Incorporating iris yellow spot resistance into an onion genotype with the horticultural traits required by growers and consumers is not a trivial undertaking. Artificial inoculation of IYSV in cultivar screening and breeding trials may allow heritable host resistance to be observed under controlled environmental conditions, but disease symptoms are difficult to produce on onion by mechanical inoculation with IYSV (62). Therefore, research is needed to isolate the genotypic components of disease resistance/tolerance from the complex interactions of thrips host selection, tolerance, uneven thrips distribution, and inherent differences in vigor and yield among genotypes. If other abiotic or biotic plant stresses are superimposed on these interactions, disentangling cause from effect becomes exceedingly difficult. It is possible to select for individuals with fewer or less severe symptoms of iris yellow spot under field conditions, but it may be unclear if the phenotype is heritable or simply the result of experimental conditions imposed by conditions of that trial. Selection by breeders is difficult because resistant individuals or families must be identified recursively for production of subsequent generations. Consequently, cultivars with high levels of resistance likely will not be available in the next 5 to 10 years. In the interim, growers will have to rely on cultivars with moderate levels of resistance or tolerance to iris yellow spot.

One possible approach for developing resistance to IYSV may be through generating transgenic onion lines that express a portion of the IYSV nucleocapsid protein gene. Pathogen-derived resistance has been used successfully for several diseases caused by tospoviruses, and a transformation system for onion has been developed (36). High levels of resistance could be introduced into cultivars adapted to specific regions, such as the western United States. However, consumer acceptance of genetically modified foods, especially of a vegetable crop consumed directly, remains challenging. It is unlikely that such resistance will be available commercially in the near future.

Development of ecologically based onion production systems that consider the interactions of multiple pests, horticultural practices, and environmental quality should be a long-term research priority. What crop rotation schemes minimize overwintering of the pathogen and vector? Does the type of planting material (i.e., bulbs, seed, or transplants) influence epidemic development? How do other pests respond when planting patterns and populations are modified? What is the economic injury level for thrips when iris yellow spot is a threat, and how does this vary among cultivars? Are insecticides, herbicides, and fungicides used routinely in onion production compatible with biologically based pest management? What cultural and biological tactics can reduce or replace conventional insecticides for 
thrips management? Researchers and extension specialists are now addressing these and other questions central to the development of sustainable and profitable management strategies for iris yellow spot and thrips.

\section{Acknowledgments}

The support and insights provided by numerous growers, collaborators, and technical personnel made this research and manuscript possible. We acknowledge the contributions of James Moyer, North Carolina State University, toward elucidation of the etiology of Iris yellow spot virus on onion. We thank Fred Crowe, Oregon State University, for generously providing a photo for Figure 3, in addition to those provided by the authors. We also thank Cindy Ocamb, Oregon State University, and Robert Martin, USDA-ARS Horticultural Crops Research Laboratory, for their critical review of an earlier draft of the manuscript. Financial support for much of the research mentioned in this manuscript was provided by U.S. onion growers and shippers in Colorado, Idaho, Oregon, and Washington; the Columbia Basin Vegetable Seed Association, EPA region 8, Pacific Northwest Vegetable Association, Washington State Commission on Pesticide Registration, and the USDA Western Region IPM Center; the Agricultural Experiment Stations of Colorado State University, University of Idaho, and Washington State University; and Bayer CropScience and Syngenta Crop Protection. Publication costs for this article were generously covered by: California Garlic and Onion Research Advisory Board, Colorado Onion Association, Crookham Company, EPA Region 8, Idaho Onion Growers Association, Malheur County Onion Growers Association, National Onion Association, Nevada Onion and Garlic Committee, Nunhems USA, Pacific Northwest Vegetable Association, Syngenta Crop Protection, and Western Oregon Onion Commission.

\section{Literature Cited}

1. Abad, J. A., Speck, J., Mohan, S. K., and Moyer, J. W. 2003. Diversity of the Iris yellow spot virus $\mathrm{N}$ gene in the USA. (Abstr.) Phytopathology 93:S1.

2. Al-dosari, S. A. 1995. Development of an IPM system for onion thrips (Thrips tabaci Lindemann) as a pest of bulb onions. Ph.D. diss. Colorado State University, Fort Collins.

3. Allen, J. K. M., Scott-Dupree, C. D., Tolman, J. H., and Harris, C. R. 2005. Resistance of Thrips tabaci to pyrethroid and organophosphorus insecticides in Ontario, Canada. Pest Manag. Sci. 61:809-815.

4. Anith, K. N., Momol, M. T., Kloepper, J. W., Marois, J. J., Olson, S. M., and Jones, J. B. 2004. Efficacy of plant growth-promoting rhizobacteria, acibenzolar- $S$-methyl, and soil amendment for integrated management of bacterial wilt on tomato. Plant Dis. 88:669-673.

5. Babu, R. M., Sajeena, A., Samundeeswari, A. V., Sreedhar, A., Vidhyasekeran, P., and Reddy, M. S. 2003. Induction of bacterial blight (Xanthomonas oryzae pv. oryzae) resistance in rice by treatment with acibenzolar-S-methyl. Ann. Appl. Biol. 143:333-340.

6. Barbour, J. D., and Bradenburg, R. L. 1994. Vernal infusion of thrips into North Carolina peanut fields. J. Econ. Entomol. 87:446-451.

7. Ben Moussa, A., Marrakchi, M., and Makni, M. 2005. Characterisation of Tospovirus in vegetable crops in Tunisia. Infection, Genet. Evol. 5:312-322.

8. Boyd, V. 2003. A jumbo threat. The Grower 36:10-11.

9. Brar, K. S., Sidhu, A. S., and Chadha, M. L. 1993. Screening onion varieties for resistance to Thrips tabaci Lind. and Helicoverpa armigera (Hubner). J. Insect Sci. 6:123-124.

10. Brewster, J. L. 1994. Onions and Other Vege- table Alliums. CAB International, Oxon, UK.

11. Brown, S., Todd, J., Culbreath, A., Baldwin, J., Beasley, J., Kemerait, B., and Pappu, H. 2001. Tomato spotted wilt of peanut: Identifying and avoiding high-risk situations. Bull. 1165, University of Georgia, Athens.

12. Bullock, J. A. 1963. Thysanoptera associated with pyrethrum, and the control of Thrips tabaci Lind. Trop. Agric. 40:329-335.

13. Camann, M. A., Culbreath, A. K., Pickering, J., Todd, J. W., and Demski, J. W. 1995. Spatial and temporal patterns of spotted wilt epidemics in peanut. Phytopathology 85:879-885.

14. Cho, K., Eckel, C. S., Walgenbach, J. F., and Kennedy, G. G. 1995. Overwintering of thrips (Thysanoptera: Thripidae) in North Carolina. Environ. Entomol. 24:58-67.

15. Cole, D. L. 1999. The efficacy of acibenzolarS-methyl, an inducer of systemic acquired resistance, against bacterial and fungal diseases of tobacco. Crop Prot. 18:267-273.

16. Córdoba-Sellés, C., Martínez-Priego, L., Muńoz-Gómez, R., and Jordá-Gutiérrez, C. 2005. Iris yellow spot virus: A new onion disease in Spain. Plant Dis. 89:1243.

17. Cortês, I., Aires, A., Pereira, A. M., Goldbach, R., Peters, D., and Kormelink, R. 2002. Genetic organisation of Iris yellow spot virus $\mathrm{M}$ RNA: Indications for functional homology between the $G_{(C)}$ glycoproteins of tospoviruses and animal-infecting bunyaviruses. Arch. Virol. 147:2313-2325

18. Cortês, I., Livieratos, I. C., Derks, A., Peters, D., and Kormelink, R. 1998. Molecular and serological characterization of iris yellow spot virus, a new and distinct tospovirus species. Phytopathology 88:1276-1282.

19. Cosmi, T., Marchesini, E., and Martini, G. 2003. Presence and spread of tospovirus and thrip vectors in Veneto. Info. Agrario 59:69-72.

20. Coudriet, D. L., Kishaba, A. N., McCreight, J. D., and Bohn, W. G. 1979. Varietal resistance in onions to thrips (Thysanoptera: Thripidae). J. Econ. Entomol. 72:614-615.

21. Coutts, B. A., McMichael, L. A., Tesoriero, L., Rodoni, B. C., Wilson, C. R., Wilson, A. J., Persley, D. M., and Jones, R. A. C. 2003. Iris yellow spot virus found infecting onions in three Australian states. Australas. Plant Pathol. 32:555-557.

22. Coutts, B. A., Thomas-Carroll, M. L., and Jones, R. A. C. 2004. Patterns of spread of Tomato spotted wilt virus in field crops of lettuce and pepper: Spatial dynamics and validation of control measures. Ann. Appl. Biol. 145:231245.

23. Cranshaw, W. S. 2006. Colorado Insecticide Trials for Control of Thrips on Onion, 19952003. Colorado State Univ. Agric. Exp. Stn. Rep. In press.

24. Creamer, R., Sanogo, S., Moya, A., Romero, J., Molina-Bravo, R., and Cramer, C. 2004. Iris yellow spot virus on onion in New Mexico. Plant Dis. 88:1049.

25. Crowe, F. J., and Pappu, H. R. 2005. Outbreak of Iris yellow spot virus in onion seed crops in central Oregon. Plant Dis. 89:105.

26. Culbreath, A. K., Todd, J. W., and Brown, S. L. 2003. Epidemiology and management of tomato spotted wilt in peanut. Annu. Rev. Phytopathol. 41:53-75.

27. Czencz, K. 1987. The role of coloured traps in collecting thrips fauna. Pages 426-435 in: Population Structure, Genetics and Taxonomy of Aphids and Thysanoptera. Proc. Int. Sympos. Smolenice, Czechoslovakia. J. Holman, J. Pelikan, A. F. G. Dixon, and L. Weisman, eds. SPB Academic Publishing, The Hague, The Netherlands.

28. de Avila, A. C., Gama, M. I. C. S., Kitajima, E. W., and Pereira, W. 1981. Um virus do grupo vira-cabeca do tomateiro isolado de cebola (Allium cepa L.). Fitopatol. Bras. 6:525.

29. Derks, A. F. L. M., and Lemmers, M. E. C.
1996. Detection of tospoviruses in bulbous crops and transmissibility by vegetative propagation. Acta Hortic. 432:132-137.

30. Diaz-Perez, J. C., Batal, K. D., Granberry, D., Bertrand, D., Giddings, D., and Pappu, H 2003. Growth and yield of tomato on plastic film mulches as affected by Tomato spotted wilt virus. HortScience 38:395-399.

31. Doi, M., Zen, S., Okuda, M., Nakamura, H., Kato, K., and Hanada, K. 2003. Leaf necrosis disease of lisianthus (Eustoma grandiflorum) caused by Iris yellow spot virus. Japanese J. Phytopathol. 69:181-188.

32. du Toit, L. J. 2005. Iris yellow spot virus of onion. Proc. Great Lakes Fruit, Vegetable, and Farm Market Expo, Monroe, MI. Michigan State Hortic. Soc., Hartford, MI.

33. du Toit, L. J., Pappu, H. R., Druffel, K. L., and Pelter, G. Q. 2004. Iris yellow spot virus in onion bulb and seed crops in Washington. Plant Dis. 88:222.

34. du Toit, L. J., and Pelter, G. Q. 2005. Susceptibility of storage onion cultivars to iris yellow spot in the Columbia Basin of Washington, 2004. Biol. Cultural Tests 20:V006.

35. du Toit, L. J., Pelter, G. Q., and Pappu, H. R. 2004. IYSV challenges to the onion seed industry in Washington. Pages 213-217 in: Proc. Natl. Allium Res. Conf., Grand Junction, CO. Colorado State University, Fort Collins.

36. Eady, C. C., Weld, R. J., and Lister, C. E. 2000. Agrobacterium tumefaciens-mediated transformation and transgenic-plant regeneration of onion (Allium cepa L.). Plant Cell Rep. 19:376-381.

37. Edelson, J. V., Cartwright, B., and Royer, T. A 1989. Economics of controlling onion thrips (Thysanoptera: Thripidae) on onions with insecticides in south Texas. J. Econ. Entomol 82:561-564.

38. Fichtner, S. M., Gent, D. H., Schwartz, H. F., Cranshaw, W. S., Mahaffey, L., and Khosla, R. 2004. Geospatial relationships of Iris yellow spot virus and thrips to onion production in Colorado. Pages 149-151 in: Proc. Natl. Allium Res. Conf., Grand Junction, CO. Colorado State University, Fort Collins

39. Fournier, F., Boivin, G., and Stewart, R. K. 1995. Effect of Thrips tabaci (Thysanoptera Thripidae) on yellow onion yields and economic thresholds for its management. J. Econ. Entomol. 88:1401-1407.

40. Gent, D. H., and Schwartz, H. F. 2005. Management of Xanthomonas leaf blight of onion with a plant activator, biological control agents, and copper bactericides. Plant Dis. 89:631-639.

41. Gent, D. H., Schwartz, H. F., and Khosla, R. 2004. Distribution and incidence of Iris yellow spot virus in Colorado and its relation to onion plant population and yield. Plant Dis. 88:446452.

42. Gent, D. H., Schwartz, H. F., and Khosla, R. 2004. Managing Iris yellow spot virus of onion with cultural practices, host genotype, and novel chemical treatments. (Abstr.) Phytopathology $94: \mathrm{S} 34$

43. Gera, A., Cohen, J., Salomon, R., and Raccah, B. 1998. Iris Yellow Spot Tospovirus detected in onion (Allium cepa) in Israel. Plant Dis. 82:127.

44. Gera, A., Kritzman, A., Beckelman, H., Cohen, J., and Raccah, B. 2002. Detection of Iris yellow spot virus in lisianthus. Acta Hortic. 568:43-49.

45. Gera, A., Kritzman, A., Cohen, J., and Raccah, B. 1998. Tospoviruses infecting bulb crops in Israel. Pages 86-87 in: Recent Progress in Tospovirus and Thrips Research. D. Peters and R. Goldbach, eds. Int. Sympos. Tospoviruses Thrips Floral Vegetable Crops 4th. Wagengingen, The Netherlands.

46. German, T. L., Ullman, D. E., and Moyer, J. W. 1992. Tospoviruses: Diagnosis, molecular 
biology, phylogeny, and vector relationships. Annu. Rev. Phytopathol. 30:315-348.

47. Ghotbi, T., Shahraeen, N., and Winter, S. 2005. Occurrence of tospoviruses in ornamental and weed species in Markazi and Tehran provinces in Iran. Plant Dis. 89:425-429.

48. Gitaitis, R. D., Dowler, C. C., and Chalfant, R. B. 1998. Epidemiology of tomato spotted wilt in pepper and tomato in southern Georgia. Plant Dis. 82:752-756.

49. Gorlach, J., Volrath, S., Knauf-Beiter, G., Hengy, G., Beckhove, U., Kogel, K. H., Oostendorp, M., Staub, T., Ward, E., Kessman, H., and Ryals, J. 1996. Benzothiadiazole, a novel class of inducers of systemic acquired resistance, activates gene expression and disease resistance in wheat. Plant Cell 8:629-643.

50. Groves, R. L., Walgenbach, J. F., Moyer, J. W., and Kennedy, G. G. 2002. The role of weed hosts and tobacco thrips, Frankliniella fusca, in the epidemiology of Tomato spotted wilt $v$ irus. Plant Dis. 86:573-582.

51. Hall, J. M., Mohan, K., Knott, E. A., and Moyer, J. W. 1993. Tospoviruses associated with scape blight of onion (Allium cepa) seed crops in Idaho. Plant Dis. 77:952.

52. Hammon, R. 2004. Managing thrips in western Colorado onions. Page 107 in: Proc. 2004 Natl. Allium Res. Conf., Grand Junction, CO. Colorado State University, Fort Collins

53. Jensen, L., and Shock, C. C. 2004. The effects of soft insecticides on thrips populations in red onions. Pages 179-183 in: Proc. 2004 National Allium Res. Conf., Grand Junction, CO. Colorado State University, Fort Collins.

54. Jensen, L., Simko, B., Shock, C. C., and Saunders, L. D. 2003. A two-year study on alternative methods for controlling onion thrips (Thrips tabaci) in Spanish onions. Oregon State Univ., Malheur Exp. Stn. Spec. Rep. 1048:94-106

55. Jones, D. R. 2005. Plant viruses transmitted by thrips. Eur. J. Plant Pathol. 113:119-157.

56. Jones, H. A., Bailey, S. F., and Emsweler, S. 1934. Thrips resistance in onion. Hilgardia 8:215-252.

57. Kessman, H., Staub, T., Hofmann, C., Maetzke, T., Herzog, J., Ward, E., Uknes, S., and Ryals, J. 1994. Induction of systemic acquired disease resistance in plants by chemicals. Annu. Rev. Plant Pathol. 12:439-459.

58. Kirk, W. D. J. 1984. Ecologically selective coloured traps. Ecol. Entomol. 9:35-41.

59. Kirk, W. D. J. 1997. Distribution, abundance, and population dynamics. Pages 217-257 in: Thrips as Crop Pests. T. Lewis, ed. CAB Int., New York.

60. Kovachevsky, I., and Markov, M. 1958. Dienekrotische Bronze fleck-enkrankheit der Tomaten. Inst. Pflsch. (Sofia) 1:5.

61. Kritzman, A., Beckelman, H., Alexandrov, S., Cohen, J., Lampel, M., Zeidan, M., Raccah, B., and Gera, A. 2000. Lisianthus leaf necrosis: A new disease of lisianthus caused by Iris yellow spot virus. Plant Dis. 84:1185-1189.

62. Kritzman, A., Lampel, M., Raccah, B., and Gera, A. 2001. Distribution and transmission of Iris yellow spot virus. Plant Dis. 85:838-842.

63. Kumar, N. K. K., and Rawal, R. D. 1999. Onion thrips, Thrips tabaci, a vector of onion tospovirus. Insect Environ. 5:52.

64. Lall, B. S., and Singh, L. M. 1968. Biology and control of the onion thrips in India. J. Econ. Entomol. 61:676-679.

65. Lewis, T. 1973. Thrips. Their Biology, Ecology and Economic Importance. Academic Press, London.

66. Lewis, T. 1997. Thrips as Crop Pests. CAB Int., New York.

67. Louws, F. J., Wilson, M., Campbell, H. L., Cuppels, D. A., Jones, J. B., Shoemaker, P. B., Sahin, F., and Miller, S. A. 2001. Field control of bacterial spot and bacterial speck of tomato using a plant activator. Plant Dis. 85:481-488.

68. Lu, F. M. 1990. Color preference and using silver mulches to control the onion thrips, Thrips tabaci Lindeman. Chinese J. Entomol./Zhonghua Kunchong 10:337-342.

69. Marois, J. J., and Wright, D. L. 2003. Effect of tillage system, phorate, and cultivar on tomato spotted wilt of peanut. Agron. J. 95:386-389.

70. Mavric, I., and Ravnikar, M. 2000. Iris yellow spot tospovirus in Slovenia. Pages 223-225 in: Proc. Congr. Eur. Found. Plant Pathol. 5th. Taormina, Italy.

71. McKenzie, C. L., Cartwright, B., Miller, M. E., and Edelson, J. V. 1993. Injury to onions by Thrips tabaci (Thysanoptera: Thripidae) and effects of thrips on bulb onions. J. Econ. Entomol. 80:930-932.

72. McPherson, R. M., Culbreath, A. K., Stephenson, M. G., and Jones, D. C. 1995. Impact of transplant date and insecticide control practices on the incidence of tomato spotted wilt virus and insect pests of flue-cured tobacco. Tobacco Sci. 39:30-37.

73. McPherson, R. M., Pappu, H. R., Csinos, A. S., and Bertrand, P. F. 1997. Influence of dichloropropene, volunteer peanut, and thrips control practices on the abundance of insect pests and incidence of tomato spotted wilt in flue-cured tobacco. Tobacco Sci. 41:91-102.

74. Miller, M. E., Saldana, R. R., Black, M. C., and Pappu, H. R. 2006. First Report of Iris yellow spot virus on onion (Allium cepa) in Texas. Plant Dis. 90:1359.

75. Mohan, S. K. 2004. IYSV symptoms and etiology: Observations since 1989. Page 105 in: Proc. 2004 Natl. Allium Res. Conf., Grand Junction, CO. Colorado State University, Fort Collins.

76. Mohan, S. K., and Moyer, J. W. 2004. Iris yellow spot virus in onion seed and bulb crops. (Abstr.) Phytopathology 94:S153.

77. Mohan, S. K., Knott, E. A., Allen, T. C., Jr., and Wilson, D. O., Jr. 1991. Evidence for association of Tomato spotted wilt virus with a scape blight disease of onion seed crops in Idaho and Oregon. Pages 26-31 in: Proc. Natl. Onion Res. Conf., Savannah, GA. University of Georgia, Athens

78. Mohan, S. K., and Wilson, D. O., Jr. 1989. Scape blight of onion. Pages 103-104 in: Proc. Natl. Onion Res. Conf., Boise, ID. University of Idaho, Moscow.

79. Molenaar, N. D. 1984. Genetics, thrips (Thrips tabaci L.) resistance and epicuticular wax characteristics of nonglossy and glossy onions (Allium cepa L.). Diss. Abstr., B (Sciences and Engineering) 45:1075B

80. Momol, M. T., Olson, S. M., Funderburk, J. E., Stavisky, J., and Marois, J. J. 2004. Integrated management of tomato spotted wilt on fieldgrown tomatoes. Plant Dis. 88:882-890.

81. Moyer, J. W. 1999. Tospoviruses (Bunyaviridae). Pages 1803-1807 in: Encyclopedia of Virology. A. Granoff and R. G. Webster, eds. Academic Press, San Diego, CA.

82. Moyer, J. W., Abad, J. A., Ullman, D., and Mohan, K. 2003. INSV and IYSV: The other Tospoviruses in the United States. (Abstr.) Phytopathology 93:S115.

83. Moyer, J. W., and Mohan, S. K. 1993. Tospoviruses associated with scape blight of onion ( $\mathrm{Al}$ lium cepa) seed crops in Idaho. (Abstr.) National Onion Res. Conf., Ithaca, NY.

84. Mullis, S. W., Gitaitis, R. D., Nischwitz, C., Csinos, A. S., Rafael Mallaupoma, Z. C., and Inguil Rojas, E. H. 2006. First report of onion (Allium cepa) naturally infected with Iris yellow spot virus in Peru. Plant Dis. 90:377.

85. Mullis, S. W., Langston, D. B., Jr., Gitaitis, R. D., Sherwood, J. L., and Csinos, A. C. 2004. First report of Vidalia onion (Allium cepa) naturally infected with Tomato spotted wilt virus and Iris yellow spot virus (family Bunyaviridae, genus Tospovirus) in Georgia. Plant Dis. 88:1285

86. Murai, T. 2004. Current status of the onion thrips, Thrips tabaci, as pest thrips in Japan. Agrochem. Jpn. 84:7-10.

87. Nagata, T., Almeida, A. C. L., Resende, R. de O., and de Avila, A. C. 1999. The identification of the vector species of Iris yellow spot tospovirus occurring on onion in Brazil. Plant Dis. 83:399.

88. National Agricultural Statistics Service. 2006. Ag Update. USDA/CASS, Lakewood, $\mathrm{CO}$.

89. Nischwitz, C., Mullis, S. W., Csinos, A. S. Langston, D. B., Sparks, A. N., Torrance, R. L., Rafael Mallaupoma, Z. C., Inguil Rojas, E. H., and Gitaitis, R. D. 2006. Phylogenetic analysis of the $\mathrm{N}$ gene links Georgia strains of Iris yellow spot virus to strains from Peru. (Abstr.) Phytopathology 96:S84.

90. Okuda, M., and Hanada, K. 2001. RT-PCR for detecting five distinct Tospovirus species using degenerate primers and dsRNA template. J. Virol. Methods 96:149-156.

91. Pappu, H. R., Csinos, A. S., McPherson, R M., Jones, D. C., and Stephenson, M. G. 2000. Effect of acibenzolar-S-methyl and imidacloprid on suppression of Tomato spotted wilt tospovirus in flue-cured tobacco. Crop Prot. 19:349-354.

92. Pappu, H. R., du Toit, L. J., Schwartz, H. F., and Mohan, K. 2006. Sequence diversity of the nucleoprotein gene of Iris yellow spot virus (genus Tospovirus, family Bunyaviridae) isolates from the western region of the United States. Arch. Virol. 151:1015-1023.

93. Pappu, H. R., Hellier, B. C., and Dugan, F. M. 2006. Wild Allium spp. as natural hosts of Iris yellow spot virus. Plant Dis. 90:378.

94. Pappu, H. R., Pappu, S. S., Jain, R., Bertrand, P. F., Culbreath, A. K., McPherson, R., and Csinos, A. S. 1998. Sequence characteristics of natural populations of Tomato spotted wilt tospovirus infecting flue-cured tobacco in Georgia. Virus Genes 17:167-175.

95. Parrella, M. P., and Lewis, T. 1997. Integrated pest management in field crops. Pages 595614 in: Thrips as Crop Pests. T. Lewis, ed. CAB Wallingford, Oxon, UK.

96. Pozzer, L., Bezerra, I. C., Kormelink, R. Prins, M., Peters, D., Resende, R. de O., and de Avila, A. C. 1999. Characterization of a tospovirus isolate of Iris yellow spot virus associated with a disease in onion fields in Brazil. Plant Dis. 83:345-350.

97. Pozzer, L., Nagata, T., Lima, M. I., Kitajima, E. W., Resende, R. de O., and de Avila, A. C. 1994. "Sapeca": An onion disease in SubMedio Sao Francisco region, Brazil, is caused by a tospovirus with a serologically distinct nucleocapsid protein. Fitopatol. Bras. 19:321.

98. Puche, H., Berger, R. D., and Funderburk, J. E. 1995. Population dynamics of Frankliniella thrips and progress of tomato spotted wilt virus. Crop Prot. 14:577-583.

99. Ravi, K. S., Kitkaru, A. S., and Winter, S 2006. Iris yellow spot virus in onions: A new (record from India. Plant Pathol. 55:288.

100. Reitz, S. R. 2002. Seasonal and within plant distribution of Frankliniella thrips (Thysanoptera: Thripidae) in north Florida tomatoes Fla. Entomol. 85:431-439.

101. Reitz, S. R., Yearby, E. L., Funderburk, J. E., Stavisky, J., Momol, M. T., and Olson, S. M 2003. Integrated management tactics for Frankliniella thrips (Thysanoptera: Thripidae) in field-grown pepper. J. Econ. Entomol. 96:1201-1214

102. Riley, D. G., and Pappu, H. R. 2000. Evaluation of tactics for management of thripsvectored Tomato spotted wilt virus in tomato. Plant Dis. 84:847-852.

103. Robène-Soustrade, I., Hostachy, B., RouxCuvelier, M., Minatchy, J., Hédont, M. Pallas, R., Couteau, A., Cassam, N., and Wuster, G. 2006. First report of Iris yellow 


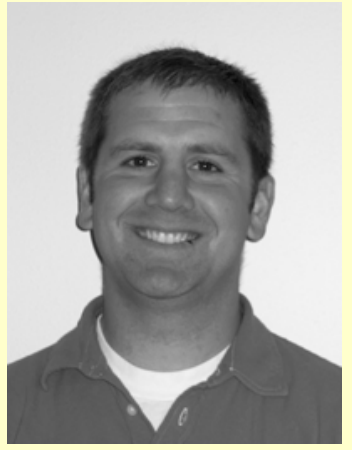

David H. Gent

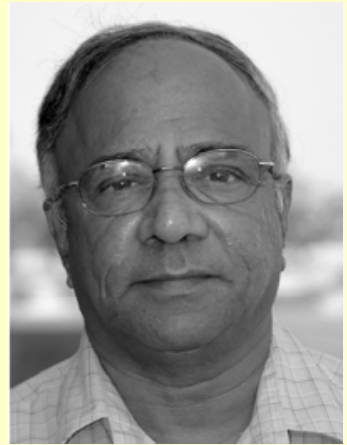

S. Krishna Mohan

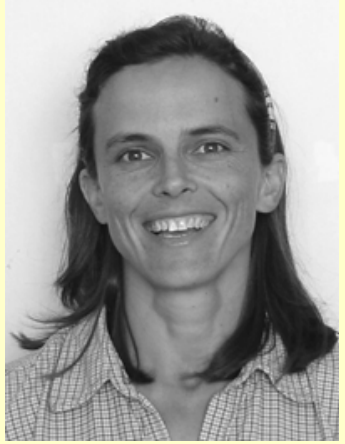

Lindsey J. du Toit

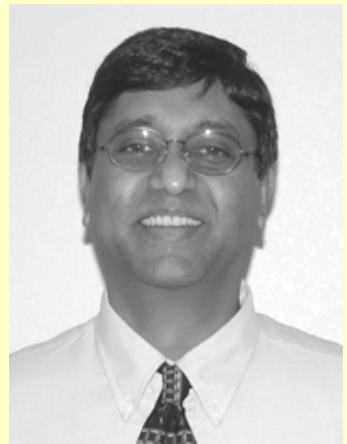

Hanu R. Pappu

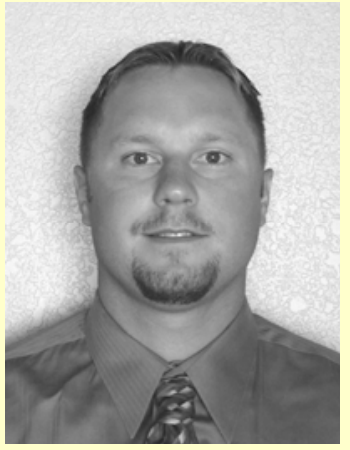

Scott F. Fichtner

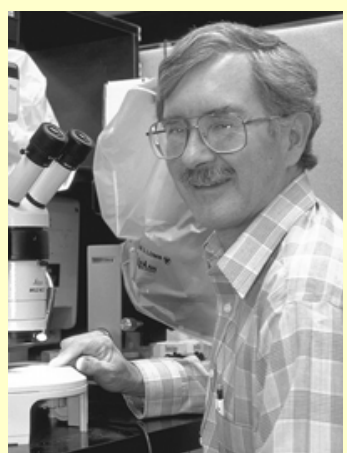

Howard F. Schwartz
Dr. Gent is a research plant pathologist with the United States Department of Agriculture-Agricultural Research Service and assistant professor (courtesy) in the Department of Botany and Plant Pathology, Oregon State University, Corvallis. He received his undergraduate education at Oregon State University in Corvallis and his M.S. and Ph.D. in plant pathology from Colorado State University in Fort Collins. His current research focuses on the epidemiology, population biology, and integrated management of powdery mildew (caused by Podosphaera macularis) and downy mildew (caused by Pseudoperonospora humuli) of hops. He leads a multidisciplinary team of researchers developing coordinated production strategies for management of arthropod pests and diseases affecting hops.

Dr. du Toit is the vegetable seed pathologist for Washington State University (WSU). She completed her undergraduate education at the University of Natal in Pietermaritzburg in 1991, majoring in plant pathology, and her M.S. (1995) and Ph.D. (1998) degrees at the University of Illinois at UrbanaChampaign, majoring in plant pathology. Her Ph.D. dissertation, under the direction of Jerald Pataky, was on common smut of sweet corn caused by Ustilago maydis. Currently, she is an associate scientist \& extension specialist E3 in the WSU Department of Plant Pathology. Her research and extension program is based at the WSU Mount Vernon NWREC, with a focus on the etiology, epidemiology, and management of diseases affecting small-seeded vegetable seed crops in Washington.

Mr. Fichtner is an agronomist for Western Farm Service in Fresno, CA. He completed his undergraduate degree at California State University, Fresno, majoring in plant sciences with an emphasis in plant health in 1998. He received his M.S. degree in plant pathology from Texas A\&M University in 2001. Currently, Scott is completing his Ph.D. dissertation under the direction of Howard F. Schwartz at Colorado State
University in the field of plant pathology. His dissertation is focused on quantification of spatial and temporal patterns and spread of Iris yellow spot virus in onion.

Dr. Mohan is a professor of plant pathology and extension plant pathologist at the Parma Research \& Extension Center of the University of Idaho, Parma. He received his M.S. and Ph.D. in plant pathology from the Indian Agricultural Research Institute, New Delhi, India. His research interests are in the area of etiology, epidemiology, and management of diseases of seed, vegetable, and fruit crops. His current focus is on diseases of sweet corn, onion, and fire blight in rosaceous plants.

Dr. Pappu is an associate professor and President Samuel $\mathrm{H}$. Smith Endowed Chair in Plant Virology in the Department of Plant Pathology, Washington State University, Pullman. He obtained his B.S. from Agricultural College, Bapatla, India, M.S. from the Indian Agricultural Research Institute, New Delhi, and Ph.D. from the University of Alberta, Edmonton. His research focuses on characterization and control of viruses of vegetables, ornamentals, and small grains, with emphasis on virus diagnostics, genomics, molecular epidemiology, and the use of conventional and biotechnological approaches for virus management.

Dr. Schwartz is a professor of plant pathology and extension specialist in the Department of Bioagricultural Sciences and Pest Management at Colorado State University. He received a B.S. in agriculture and Ph.D. in plant pathology from the University of Nebraska, and an M.S. in plant pathology from the University of Minnesota. His current research and extension responsibilities focus on integrated management of rusts, bacterial wilt, and white mold of dry bean; and bacterial diseases and Iris yellow spot virus of onion; with emphasis on disease resistance, cultural practice modification, and timely application of pesticides in response to environmental monitoring and crop/pest modeling. 
spot virus in onion bulb- and seed-production fields in Réunion Island. Plant Pathol. 55:288.

104. Romero, A. M., Kousik, C. S., and Ritchie, D. F. 2001. Resistance to bacterial spot in bell pepper induced by acibenzolar- $S$-methyl. Plant Dis. 85:189-194.

105. Rosales, M., Pappu, H. R., Lopez, L., Mora, R., and Aljaro, A. 2005. Iris yellow spot virus in onion in Chile. Plant Dis. 89:1245.

106. Rösingh, C. 1980. Untersuchungen uber die resistenz der kuherbse, Vigna unguiculata (L.) Walp., gegen Megalurothrips sjostedti (Trybom) (Thysanoptera, Thripidae). Hochschulsammlung Naturwissenschaft: Biologie, Band 9. Hachschulverlag, Freiburg, Germany.

107. Saxena, R. C. 1977. Integrated approach for the control of Thrips tabaci Lind. Indian J. Agric. Sci. 45:434-436.

108. Schwartz, H. F., Brown, W. M., Jr., Blunt, T., and Gent, D. H. 2002. Iris yellow spot virus on onion in Colorado. Plant Dis. 86:560.

109. Schwartz, H. F., Epsky, N. D., and Capinera, J. L. 1988. Onion transplant pink root and thrips contamination, and their control in Colorado. Appl. Agric. Res. 3:71-74.

110. Schwartz, H. F., Gent, D. H., Fichtner, S., Hammon, R. W., and Khosla, R. 2004. Integrated management of Iris yellow spot virus in onion. Pages 207-212 in: Proc. 2004 Natl. Allium Res. Conf., Grand Junction, CO. Colorado State University, Fort Collins.

111. Schwartz, H. F., Mohan, S. K., Havey, M. J., and Crowe, F. J. 2006. Introduction. Compendium of Onion and Garlic Diseases and Pests. 2nd ed. H. F. Schwartz and S. K. Mohan, eds. American Phytopathological Society, St. Paul, $\mathrm{MN}$.
112. Sconyers, L. E., Brenneman, T. B., Stevenson, K. L., and Mullinix, B. G. 2005. Effects of plant spacing, inoculation date, and peanut cultivar on epidemics of peanut stem rot and tomato spotted wilt. Plant Dis. 89:969-974.

113. Shelton, A. M., Nault, B. A., Plate, J., and Zhao, J. Z. 2003. Regional and temporal variation in susceptibility to lambda-cyhalothrin in onion thrips, Thrips tabaci (Thysanoptera:Thripidae), in onion fields in New York. J. Econ. Entomol. 96:1843-1848.

114. Shelton, A. M. Nyrop, J. P., North, R. C., Petzoldt, C., and Foster, R. 1987. Development and use of a dynamic sequential sampling program for onion thrips, Thrips tabaci (Thysanoptera: Thripidae) on onion. J. Econ. Entomol. 80:1051-1056.

115. Shock, C. C., Jensen, L. B., Hobson, J. H., Seddigh, M., Shock, B. M., Saunders, L. D., and Stieber, T. D. 1999. Improving onion yield and market grade by mechanical straw application to irrigation furrows. HortTechnology 9:251-253

116. Singh, D., Ramzan, M., and Gill, S. P. S. 1977. Field screening of onion cultivars at Ludhiana. Punjab Hortic. J. 23:242-243.

117. Smith, T. N., Wylie, S. J., Coutts, B. A., and Jones, R. A. C. 2006. Localized distribution of Iris yellow spot virus within leeks and its reliable large-scale detection. Plant Dis. 90:729-733.

118. Stavisky, J., Funderburk, J. E., Brodbeck, B. V., Olson, S. M., and Andersen, P. C. 2002. Population dynamics of Frankliniella spp. and tomato spotted wilt incidence as influenced by cultural management tactics in tomato. J. Econ. Entomol. 95:1216-1221.
119. Sticher, L., Mauchi-Mani, B., and Metraux, J. P. 1997. Systemic acquired resistance. Annu. Rev. Phytopathol. 35:235-270.

120. Szirmai, J. 1958. Virusveszely a makoi hagymatermesztesben. Novenytermeles 7:63.

121. Terry, L. I. 1997. Host selection, communication and reproductive behaviour. Pages 175 196 in: Thrips as Crop Pests. T. Lewis, ed CAB Int., Wallingford, UK.

122. Thaler, J. S., Karban, R., Ullman, D. E. Boege, K., and Bostock, R. M. 2002. Crosstalk between jasmonate and salicylate plant defense pathways: Effects on several plant parasites. Oecologia 131:227-235.

123. Thaler, J. S., Stout, M. J., Karban, R., and Duffy, S. S. 2001. Jasmonate-mediated in duced plant resistance affects community of herbivores. Ecol. Entomol. 26:312-324.

124. Thomas, J., Schreiber, A., Pelter, G. Q., and Havens, D. 1997. Washington's Small-Seeded Vegetable Seed Industry. Washington State Univ. Ext. Bull. No. 1829.

125. Tsompana, M., Abad, J., Purugganan, M., and Moyer, J. W. 2005. The molecular population genetics of the Tomato spotted wilt virus (TSWV) genome. Mol. Ecol. 14:53-66.

126. Ullman, D. E., Meideros, R., Campbell, L. R., Whitfield, A. E., Sherwood, J. L., and German, T. L. 2002. Thrips as vectors of tospoviruses. Adv. Bot. Res. 36:113-140.

127. Verma, S. K. 1966. Studies on the host preference of the onion thrips, Thrips tabaci Lindeman to the varieties of onion. Indian J. Entomol. 28:396-398

128. Whitfield, A. E., Ullman, D. E., and German, T. L. 2005. Tospovirus-thrips interactions Annu. Rev. Phytopathol. 43:459-489. 